\title{
Understanding of Marriage and the Concept of Natural Law
}

Karol Jasiński**

karol.jasinski@uwm.edu.pl https://doi.org/10.31192/np.17.3.2

UDK / UDC: 27-452:27-428

27-423

Pregledni članak / Review

Primljeno / Received: 20. ožujka 2019. / March 20, 2019

Prihvaćeno / Accepted: 27. lipnja / Jun 27, 2019

The author of the article set himself two main goals. The first goal was to outline, on the background of a specified definition of marriage, the fundamental changes to which the institution is currently subject (crisis of goals, privatization, divorces, concubinages, same-sex relationships). The second purpose is the presentation of problems related to the recognition of natural law, to which the proponents of traditional understanding of marriage as a union of man and woman appeal. The point of reference was the conviction of a certain relationship between the understanding of marriage and the underlying concept of natural law. Two basic concepts of natural law have been presented: Aristotelian-Thomistic and contemporary, whose consequences are indicated in the conclusions. Both concepts assume a certain understanding of human nature which, in the first case, is treated as static (the spiritual-physical structure) and, in the second case, as dynamic (intelligent freedom).

Key words: marriage, human nature, natural law, freedom, conscience.

\footnotetext{
* Karol Jasiński, PhD, Assoc. Prof., Faculty of Theology, University of Warmia and Mazury in Olsztyn; Address: Hozjusza 15, 11-041 Olsztyn, Poland.
} 


\section{Introduction}

It is undeniable that both biological existence and social life are significant dimensions of a human being. Since man is a "biological preterm", he needs other people and communities, both at the beginning of his life and at further stages of his development. Natural communities playing an important role in developing personal identity include the family, the nation and the state. The family, which is consequence of a previously contracted marriage, is of particular importance.

The analyses presented below have two fundamental aims. The first one is to outline, against a specific definition of marriage, significant changes which this institution is currently undergoing. The second aim is to show problems related to the approach to natural law, which the supporters of the traditional understanding of marriage as a union of a man and a woman refer to, since it seems that such a definition of marriage assumes an appropriate concept of natural law. In the $20^{\text {th }}$ century, under the influence of certain philosophical trends, a new understanding began to prevail. It was also applied by representatives of the so-called "new theology" (e.g. Josef Fuchs, Franz Böckle, Alfons Auer, Klaus Demmer, Bernhard Häring and Peter Knauer). Consequently, attempts were made to redefine the notion of marriage and to use this term to describe other, not only heterosexual, forms of interpersonal relations. The point of reference for this discussion is, therefore, the belief about a certain relationship between the understanding of marriage and the underlying concept of natural law.

\section{Marriage in the time of changes}

Following the views of a Polish ethicist, Tadeusz Slipko, three principal viewpoints in the discussion on understanding the marriage can be distinguished: naturalistic, sociological-institutional and based on natural law. Supporters of the former emphasize that marriage is a human concept, which took an inseparable monogamous form as a result of historical developments. In its external content, it is specified by the right of individuals to satisfy their drive towards pleasure and happiness (e.g. Jean J. Rousseau, John S. Mill, Herbert Spencer). Representatives of the second viewpoint believe that marriage is a product of society. However, it has supraindividual reality, distinct and independent of the will of individuals (e.g. Emil Durkheim, Marxists). Supporters of the third approach emphasize that this is an institution of natural law, by the power of which it was constituted as monogamous and inseparable. Its aim is personal improvement of the married couple and procreation (e.g. Christian ethicists). ${ }^{1}$

1 Tadeusz ŚLIPKO, Zarys etyki szczegółowej, Vol. 2, Etyka społeczna, Kraków, Wydawnictwo Apostolstwa Modlitwy, 2005, 144-145. 
Until recently, a common belief was held that marriage and family, as its consequence, are just natural forms of social life. It was considered that they had biological and psychological backgrounds. One of them is sexual differentiation of human beings, permeating them entirely, both as regards somatically and psychologically. Human personality is subject to enhancement, among others, in this aspect. The principal aims of marriage include giving birth to and upbringing children, as well as development of personal love, involving the entire human being. Therefore, it requires monogamy and inseparability, as both those processes are out of their nature extended in time. ${ }^{2}$

Consequently, marriage consists in a union of persons of different genders, the internal reality of which consists of the spiritual experiences of love and procreation. ${ }^{3}$ Marriage is usually defined through a description of its features. Thus, it is perceived first of all as a union of a woman and a man, recognized by law, religion or custom. It is emphasized that marriage is a legal union, i.e. it is concluded in accordance with applicable law. ${ }^{4}$

Secondly, marriage is a community of people of different gender, granting by the power of natural law mutual rights and obligations for comprehensive development in procreative love. Several reasons are provided for the genesis of marriage under natural law. First of all, emphasis is put on sexual differentiation in the biological and psychological sphere and the need to complement each other on all levels of marriage community. Secondly, the commonness of marriage in time and space speaks for its natural genesis. Thirdly, specific anthropological assumptions also have a significant impact. Man is understood as a rational being who, by the power of the primarily imperative of his moral nature, is driven towards personal improvement, which requires taking into account the social dimension. Improvement of the human being consists in the form of sexual intercourse, in which not only emotions, but also sexual activity directed towards the creation of a new life is important. The need of the human being to improve and to call to life a new human being assumes the existence of marriage as a permanent and monogamous interpersonal community. Its aim should be the development of spouses, corresponding to their personal dignity. ${ }^{5}$

Since marriage is treated as a kind of community, it is also assigned noninstitutional and informal attributes. Therefore, the unity of the separate individualities of a husband and wife, as well as the unity of purposes for which the marriage was concluded, are emphasized. The community approach to marriage emphasizes the unity of actions, community of existence, common

\footnotetext{
${ }^{2}$ Mieczysław A. KRĄPIEC, Człowiek i prawo naturalne, Lublin, Katolicki Uniwersytet Lubelski, 1975, 160-164.

3 Ślipko, Zarys etyki szczegótowej..., 141.

${ }^{4}$ Anna KOTLARSKA-MICHALSKA, Małżeństwo jako związek, wspólnota, instytucja, podsystem i rodzaj stosunku społecznego, Roczniki Socjologii Rodziny, 10 (1998) 51-52.

5 Ślipko, Zarys etyki szczegółowej..., 146-153.
} 
gathering of goods, cooperation, planning and implementing tasks together, developing a strategy for shared life, intimacy of experiences, feeling, emotional, sexual and intentional community. Marriage community is therefore a unity of expectations, unity of values, unity of actions and unity in responsibility for the permanence of the union. Unquestionably, relations matched both in terms of social and cultural features, but also in terms of personality and character features reveal a community nature. This means that people should be directed by shared motivations both at the moment of starting the union and while it lasts. If the notion of community is understood as a natural union of people for their common purpose and shared feelings, as well as concurrence of feelings and desires, then a marriage based on such foundations can be treated as a community. ${ }^{6}$

Marriage, being a union and a community between a woman and a man, makes at the same time the core of the family bringing up common children. Difference in the sexes of spouses is an inseparable element of marriage (family) to make the fulfilment of the procreation function possible. It is also related to the function of taking care of the offspring and ensuring relations between the child and the parents. Primarily, the family was the most compact social group. It was treated as a community necessary for the proper functioning of the human species. Its aim was therefore to create conditions for creating and raising children in this world. The belief in the integrity of marriage and of a nuclear (two-generation) family has been strongly reinforced in cultural circles. Such a form was heavily affected by religion, particularly the Christian faith. It helped to indicate and shape the proper form of marriage and family. Its ultimate source was God's intention. Therefore, all other forms of unions between people were considered improper. Currently, it is increasingly often emphasized that this approach towards the marriage is most justified from the perspective of a specific religion. Nevertheless, it is questioned whether it should continue to determine the shape of secular legislation governing the coexistence of people with different religious and moral backgrounds. A crisis in the traditional model of the nuclear family has been observed for several decades. This crisis is a consequence of civilisation changes. It has been noticed that the stability of marital unions is systematically decreasing in many countries. The reason is, among others, unsatisfactory involvement in marital relations. People are afraid of getting involved into deep and permanent relations with other people, for fear of losing their freedom and privacy. An increase in interest in concubinage can also be observed. Many people, even bringing up their children, function without getting married. A decrease in the number of marriages is accompanied by an increase in the number of divorces. It is even claimed that traditional marriage and family has entered a decadent phase. Nuclear family cohesion has weakened in almost every aspect. Entering into

\footnotetext{
${ }^{6}$ Kotlarska-Michalska, Matżeństwo jako zwiazek..., 54-55.
} 
marriage, people aim not only for procreation, but also want to realize other purposes. However, their aims are often divergent. Moreover, these aims sometimes predominate in their lives. These include, among others, the need for spiritual and material coexistence, love, friendship, cooperation, responsibility for oneself and the nearest person, identity of the human being and safety. Additionally, in contemporary, mobile and pluralistic, multicultural societies, a diversity of human customs concerning marriage is becoming apparent. Undoubtedly, multiculturalism has significantly contributed to the discussion concerning the plausibility of a very narrow definition of marriage. Today, its broad meaning is increasingly often used. It is emphasized that this is an agreement concluded before a representative of a society between at least two persons. It provides a specific contract concerning common law, determining the mutual rights and obligations of parties? ${ }^{7}$. It is assumed that this contract may cease to exist when both parties do not wish to fulfil their duties or if it ceases to bring notable benefits. While concluding this agreement, the issue of sexual identification and orientation of its partners is often neglected.

At the end of the $20^{\text {th }}$ century, the postulate of legalisation of unions (marriages) between people of the same sex has been strongly articulated, also becoming a subject of public debate in many states. It was the effect of overlapping social processes, also affecting the legislation. At the same time, marriage started to be perceived as an institution not so much of a public nature, as first of all private one. It became less important as the subject of state interest, treated more often as an issue of autonomous decisions of individual people. The process of marriage privatization occurred at the same time as the process of eliminating minority discrimination. The view that started to prevail was that the criterion of a different sex of partners and the condition of the legal institution of marriage can be perceived as a manifestation of discriminatory practices. What was also observed was the evolution of social attitudes towards homosexuality itself. Arguments referring to freedom, justice and certainty of legal transactions have been advanced for institutionalization of same-sex relationships. On the other hand, principal arguments against institutionalization of same-sex unions refer to religion and morality, demography and change of social relationships. Legal institutionalization of homosexual unions takes all forms differing in the scope of introduced rights and obligations, modes of regulations or the question of whether to create new legal regulations or introduce new rules into the existing legal order. However, four leading regulatory models can be observed: marriage, registered partnership, civil-law contract and concubinage. Thus, it can be claimed that the tendency to broaden the

\footnotetext{
Allan BLOOM, Umyst zamknięty. O tym, jak amerykańskie szkolnictwo wyższe zawiodto demokrację i zubożyto dusze dzisiejszych studentów, trans. Tomasz Bieroń, Poznań, Zysk i S-ka, 1997, 139-156; Anetta BRECZKO, O potrzebie redefinicji pojęć "małżeństwo" i "rodzina" we współczesnym pluralistycznym świecie. Rozważania w kontekście związków partnerskich, $M i$ scellanea historico-iuridica, 13 (2014) 2, 338-340.
} 
rights concerning informal unions to also cover homosexual partners is visible. Marriage is losing its heterosexual character and currently also includes samesex partners. Consequently, the need to redefine the notion of marriage has been increasingly often discussed. ${ }^{8}$ It is all the more important that in times following the sexual revolution, all forms of sexual relations that do not harm another person seem to be allowed. ${ }^{9}$

Therefore, marriage is undergoing a fundamental transformation process. On one hand, its crisis and sometimes disintegration is observed while, on the other, we are deal with an attempt to introduce its new forms. Their supporters do not seem to take into account existing cultural and religious conditions, or even the conditions of a biological nature, in particular in the perspective of the procreative purpose of marriage. Possibly, an increasing range of solutions offered by genetic bioengineering and medicine can provide a certain antidote against potential difficulties in this regard. However, the development of new forms of marriage has been strongly affected by the needs of individuals, particularly the need for self-fulfilment. The insights into the many biological, social and psychological aspects and functions of sexuality and relationship play also a crucial role in this development. It is worth emphasizing that a man striving for self-fulfilment shows no consideration for the condition of his nature. He wants to transgress it, as he feels its owner and principal. Therefore, he forgets about natural law, which is violated, and its very idea is increasingly often questioned.

\section{The issue of natural law}

Let us examine the issue of natural law. Obviously, the analyses presented below are not meant to be exhaustive. A principal subject of interest will be to present the main assumptions of the traditional and the contemporary concepts of natural law, which are not without effect on the understanding of marriage, and to point out to significant differences between them.

It is worth emphasizing that the very expression of "natural law" is ambiguous and its meaning is related to an understanding of nature itself.

The German philosopher Robert Spaemann observes that the word "nature" generally draws its meaning from the notion that is opposed to it, e.g. physis-nomos. "Nature" meant then, on one hand, all that was not established by nomos, techne and freedom and, on the other, what provided the conditions for the human life to exist. Consequently, nature could be the individual and

\footnotetext{
${ }_{8}^{8}$ Breczko, O potrzebie redefinicji pojęćc..., 343-348.

${ }_{9}$ Bloom, Umyst zamknięty..., 114-125.
} 
specific structure of a human being, a hypothetical initial condition of a human being or the entirety of natural phenomena. ${ }^{10}$

The metaphysicist and anthropologist Mieczysław A. Krąpiec lists about 20 meanings of the word "nature". It can be used to denote certain external or internal factors of things (e.g. God, other birth-giving nature, essence, matter, form, union of elements, being-in-itself, substance), or to denote items (e.g. cosmos, the set of created beings, the subject of natural sciences, God, products of intellect, instinct, character). Strictly speaking, nature is the essence of a given thing being the source of action. ${ }^{11}$ Such a definition of nature is supported by Krąpiec, who places it in the entire system of his philosophical thought, inspired by the works of Thomas Aquinas.

The German philosopher Berthold Wald, similar to the ideas promoted by Krąiec, mentions four principal notions of nature. First of all, there is an explicit notion of nature considered as non-created by God. It is atheleological, identified with given observations, material and non-rational. Secondly, there exists a corresponding notion of nature considered as created by God, theleological and casually rational. Thirdly, there is an explicit concept of nature considered as created, material and mechanistic. Fourthly, we also use an analogous notion of nature considered as non-created and specific form of life. $^{12}$ Wald supports the second, analogous notion of nature, which fits well within his rational and theleological concept of reality.

On the margin, it is worth observing that theological visions of the world are not popular today. Its mechanistic image started to prevail in the $18^{\text {th }}$ century, which marked the breakthrough moment. The world was also opposed to all that was supernatural and began to be treated as an autonomous being (natura pura). ${ }^{13}$

The Polish ethicist Andrzej Szostek, following the thought of the German theologian Franz Böckle, provides four basic meanings of the term "nature". First of all, nature is a priori knowledge of moral qualifications describing human deeds, which is expressed in synderesis as a call for responsible selfdetermination. Secondly, nature means the unchangeable, metaphysical nature of the human being. Thirdly, nature is manifested in an intelligible significant structure of human deeds. Fourthly, nature is a bio-physiological human system. ${ }^{14}$ It seems that the first understanding of nature as a form of human

\footnotetext{
${ }^{10}$ Robert SPAEMANN, O prehistorii pojęcia natury w XVIII w., in: Robert Spaemann, Rousseau - człowiek czy obywatel. Dylemat nowożytności, trans. Jarosław Merecki, Warszawa, Oficyna Naukowa, 2011, 85-90.

${ }^{11}$ Krąpiec, Człowiek i prawo naturalne..., 54-55.

${ }^{12}$ Berthold WALD, Natura i prawo naturalne - perspektywa historyczna, trans. Agnieszka Lekka-Kowalik, in: Andrzej Maryniarczyk, Katarzyna Stępień, Paweł Gondek (eds), Substancja. Natura. Prawo naturalne, Lublin, Polskie Towarzystwo Tomasza z Akwinu, 2006, 60-83.

${ }^{13}$ Spaemann, O prehistorii pojęcia natury..., 91-101.

${ }^{14}$ Andrzej SZOSTEK, Natura, rozum, wolność. Filozoficzna analiza koncepcji twórczego rozumu we wspótczesnej teologii moralnej, Rzym, Fundacja Jana Pawła II, 1990, 145-150.
} 
self-knowledge is currently prevailing. It also has an important effect on the contemporary concept of natural law, which consists in free and creative process of self-determination and self-fulfilment of a human being. Other definitions of nature, due to their apparent defects, meet with several objections. According to their opponents, the primary problem lies in distinguishing a specific metaphysical "constant" in the human being, as it is a historical, and therefore, changeable being. As regards the structure of deed, in their opinion, a too strong emphasis is put on the objective instead of a subjective aim, i.e. the intentions of the subject performing the deed. Finally, they charge the last one of the above-mentioned meanings of the term "nature" with biologism. The issue of biologism will be discussed later in the further part of the paper.

Krapiec distinguishes four principal concepts of natural law that were common through history. The first of them is the ancient concept of the cosmo-theological law, which mentions the divine Logos permeating the entire cosmos, including the interior of the human being, providing sense and order (stoics, Plato, Aristotle). The second can be referred to as a psychological-theological concept of natural law, which binds the human being from the inside, participating in divine ideas entered into his structure of being (Augustine of Hippo). The third concept was proposed by Thomas Aquinas and it is referred to as the theory of analogous natural law. The third concept originates from the representatives of the natural law school, who identified the natural law with orders of natural reason, isolated from eternal law (e.g. Hugo Grotius, Thomas Hobbes, Samuel Puffendorf, Baruch Spinoza, German idealists). ${ }^{15}$ Krąpiec consistently supports the concept of Aquinas, who understands nature as the essence of things, being the source of activity, and identifies the natural law with the order of reason. Man is called to read the eternal law using his reason and to be guided by it in specific conditions of his existence. However, the age of Enlightenment saw the process of absolutisation of human reason begin, which instead of reading the norms of law, started to create them on its own. Thus, natural law has also changed its character.

Let us examine how natural law was understood in the philosophical tradition which derives inspiration from Aristotelian-Thomistic thought.

This concept of natural law was based on a specific understanding of nature. The term was used to describe all that could be experienced by man, understood as a being capable of free and rational self-determination. Therefore, nature meant three things. First of all, the natural world and structures occurring in this world (e.g. social, political and economic ones), as examined by empirical sciences. Secondly, the essence of being defined as a principle of acting (e.g. freedom, intelligence). Thirdly, some categories of human acts (e.g.

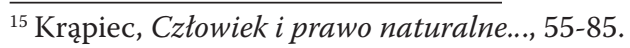


speech) ${ }^{16}$ In case of the man, nature was understood primarily as a static and dynamic structure typical for him. ${ }^{17}$ Here, we are interested in nature defined as the second out of the three meanings listed above.

This static-dynamic structure of a contingent being of man is a measure of his being and the method for his participation in the eternal law. This law is God Himself as the mind ruling the world and giving a sense to it. Because of Him, the structure of the human being is such and not another, which is manifested in inclinations for specific activities. Inclinations are the manifestations of natural law and are manifested by reason. Only a rational being, which through law must determine itself, can be the subject of law. Man, as a rational being, participates in the eternal divine law through reason. Rational human nature reflects the eternal divine law, manifested in natural inclinations for aims proper to nature, which include preserving life, the transmission of life and the development of personalities in society. Natural inclinations originate from the Absolute as the causative, model and purposeful cause. This participation of divine law in human intelligent nature is referred to as natural law. Its interpretation takes place in practical human cognition, referred to as conscience. Natural law is manifested in the voice of conscience, i.e. evaluation of practical reason, in the form of "do good". The task of man is to learn this good and to determine his actions. Since every person is unique and has his own, discovered by individual conscience, way of behaviour, natural law cannot be explicit but analogous. ${ }^{18}$ Therefore, knowledge of law depends on the knowledge of the human nature, whose conditions for full realization are manifested in natural inclinations. What is proper for a given being out of its nature and what should be realized in its activity can be determined through analogy. The normativity of nature is derived from the specific way of living of the beings created and it is always different. ${ }^{19}$

It can be observed that a rational creature is subject to eternal law in a specific and more perfect way. It participates in this law through its reasonable nature. A human being is directed by the learned law from inside, since in his conscience, he learns the truth about good that is binding for him. ${ }^{20}$

In this context, the Polish ethicist Tadeusz Ślipko defines natural law as a set of category-based, objective and absolute norms based on principal imperatives ("do good, avoid evil"), which enable rational entities to perform deeds that are internally good and to avoid acts that are internally wrong. Those

\footnotetext{
${ }^{16}$ Jarosław MERECKI, Spór o prawo naturalne. Analiza modelu argumentacji etycznej Josefa Fuchsa, Lublin, Katolicki Uniwersytet Lubelski, 2011, 17-20.

${ }^{17}$ Tadeusz STYCZEŃ, Filozoficzna koncepcja prawa naturalnego, in: Tadeusz Styczeń, Objawiać osobę, Lublin, Katolicki Uniwersytet Lubelski, 2013, 205.

${ }^{18}$ Krąpiec, Człowiek i prawo naturalne..., 196-216.

${ }^{19}$ Wald, Natura i prawo naturalne..., 74.

${ }^{20}$ Andrzej SZOSTEK, Prawo naturalne jako podstawa działania człowieka (normatywność natury ludzkiej), in: Maryniarczyk, Stępień, Gondek (eds), Substancja..., 40, 45-47.
} 
norms are within human nature. Ergo, human nature is of a moral nature. The drive towards optimum development through reaching proper goods, with the most excellent Good as the final aim and the source of happiness taking the highest place, is embedded in man. Nature is an objective order based on essential structures of the human being, taking the form of relations between the internal purposefulness of structural elements and human improvement according to the personal pattern of his excellence. This personal pattern of values is finally rooted in the Transcendental value. Improvement takes place through rational and morally fair actions, consistent with eternal law. ${ }^{21}$

Jarosław Merecki, an anthropologist and ethicist, perceives the issue of the moral character of nature in a slightly different way. In his opinion, individuals are always given human nature. However, each person is unique as an entity and cannot be reduced to the nature that is common to all people. A human being has his nature as a certain subjective structure. Nature means an essence of a given person, whom we learn on the basis of features shown by specimens of a given species. Nature in itself does not contain any obligations, which emerge only in relation to freedom. Basic inclinations of human nature are not inclinations of a human being. Man does not have to follow them, he can deny them. It must be noted that an important feature of a person is transcendence, as a result of which man is not subject to his inclinations but can control them. Natural law is the law of reason, which, however, does not create this law in a totally autonomous way, but recognizes it in the objectively existing structure. Inclinations only provide the bases of law, but not the moral natural law itself. However, they participate in eternal law. Inclinations are the reasons for activity, due to which the man learns basic goods for himself. Therefore, a person can refer to his nature in a free way. However, this does not mean that each individual can arbitrarily determine the moral sense of human nature. ${ }^{22}$

At the same time, it should also be remembered that a human being is a spiritual and carnal entity, and as such, he is a personal being. In the process of his personal development it is therefore necessary not only to respect the specificity of the spirit, but also the particularity of the body structure. It is also morally binding as subordinate and attributed to the spirit. Natural law is an act of reason, which reads it in the human nature. Still, it cannot be reduced to the act of reason, but also the normative meaning of carnality, manifested in inclinations of nature, should be taken into account. ${ }^{23}$ Therefore, man is not only a rational creature but, first of all, a rational animal. Consequently, this spiritual-carnal complexity should be respected along with its dynamism, oriented towards its full development. It is the more so that the man is much more

\footnotetext{
${ }^{21}$ Tadeusz ŚLIPKO, Zarys etyki ogólnej, Kraków, Wydawnictwo Apostolstwa Modlitwy, 2002, 278, 282, 318-320.

${ }^{22}$ Merecki, Spór o prawo naturalne..., 135-136, 143-144, 166-169, 182.

${ }^{23}$ Szostek, Natura, rozum, wolność..., 294-296.
} 
deeply constituted by this complexity than he thinks. ${ }^{24}$ Nature is therefore normative and consequently, determines the relations between men and women. ${ }^{25}$

This is important in the case of sexuality, which permeates the entire human body. The female or male sex determines the shape of humanity of the human person and reveals the direction of its development. Sexuality also has a communion-forming sense of complementing femininity and masculinity. This unity is based on sexual distinctness, due to which one's own identity is discovered. In this context, the category of gift is important. A human being is endowed with a body, which has a nuptial sense. The woman and the man learn each other and give themselves to each other through the body. Therefore, the "body language", the truth of which is normative, should be read. It should be borne in mind that each language has a spiritual and material element. Consequently, it cannot be freely developed, but already existing meanings have to be taken into account. Body language has to be read as it has been written into the bodily structure. It occurs through reason, which is read by this deeper, metaphysical and at the same time axiologically saturated truth about the reality of the body. ${ }^{26}$ Therefore, attention is paid to the theleology of gender, namely, its purposefulness. The sense of purpose directs the entire human being. ${ }^{27}$

As Polish personalist Tadeusz Styczeń emphasizes, people draw responses to the questions about the necessity of action from deepened reflection on their spiritual and carnal structure. He also observes that this structure can tell us what to do, but cannot explain why it should be done. It holds no adequate reason for the authority that we associate with the need to act. This reason can be discovered by the contingency of the human being who, in his existence and nature, depends on the Absolute. The Absolute becomes the reason for the obligation to act. Nature depends existentially on God-The Absolute, whose intentions are revealed by the aims of nature and as such are embedded in His authority. An immanent truth of nature is presented, in his opinion, as transcendental truth, i.e. the truth of God's intentions. An important role is played by reason, whose function is to read senses of truth immanently embedded in nature as God's intentions towards man. Therefore, reason does not create the truth, but can read and recognize it. It is the only instance capable of reading and announcing God's intentions. However, moral obligation is manifested itself in the voice of conscience. As a result of final explanation, it seems to be a personal call of the transcendental "You" to the human "Self". Obligation is always specified in terms of content. Its content is derived from the human nature, which is an instance communicating to the human being specific content provided by God. Nature normalizes human behaviour, but it is also normal-

\footnotetext{
${ }^{24}$ Szostek, Prawo naturalne jako podstawa dziatania człowieka..., 41, 44.

${ }^{25}$ Bloom, Umyst zamknięty..., 132.

${ }^{26}$ Szostek, Natura, rozum, wolność..., 300-306.

${ }^{27}$ Bloom, Umyst zamknięty..., 130.
} 
ized by the eternal idea of God. It is a fountain of God's intentions towards the human being and his free actions. It participates in the eternal truth of God's intentions and becomes natural law. ${ }^{28}$ Consequently, it can be seen that this concept of natural law is based on metaphysical and epistemological realism. It is actually typical for the entire Aristotelian-Tomistic tradition.

Ślipko also claims that the imperative power of natural law proves that it must have been created by an appropriate authority. No instance can be found in the contingent world that could explain this imperativeness to a satisfactory degree. In such a case, the creator of natural law can be finally only the creator of nature, i.e. God as a source of law for all creation. A causative reason of the imperativeness of natural law is therefore the act of God, which exists first in Him and is referred to as eternal law as an order of God's will establishing moral order. ${ }^{29}$

The above-mentioned concept of natural law was subject to criticism, as a result of which, several weaknesses were indicated.

One of the principal objections is the anthropomorphic image of God as the source of law and the Lord of all beings, which is implied in this concept. God seems to hold certain areas of reality and impose His will on human beings, who must recognize them as the norm of his behaviour. However, this image of God and His relations towards the world is false, as He is attributed features typical for a hierarchically-organized society. What is emphasized is that God created human beings as rational and free creatures. He does not want to deprive the human being of these attributes. ${ }^{30}$

It is also observed that the Thomistic tradition of understanding natural law includes a certain ambiguity. On one hand, it is considered equivalent to reason, capable of learning a specific being in its relation to eternal law. However, on the other hand, this law is treated as the specific order of being, which should be respected. As a result of this ambiguity, two interpretations of this law are possible: creative or naturalistic. ${ }^{31}$

Consequently, bearing in mind the views of Georg Edward Moore, an objection concerning naturalistic fallacy is put forward. Its supporters oppose any attempts to define good not only through natural features, but also through non-empirical features (e.g. God's order). This fallacy can occur in three principal forms: biologism (equating laws of nature in the sense applied in empirical sciences with moral natural law, nature regularities becoming a norm of morality), arising out of the "nature of the deed" (a subjective purpose determines the moral character of a human deed), and a theological form (natural inclina-

\footnotetext{
${ }^{28}$ Styczeń, Filozoficzna koncepcja prawa naturalnego..., 207-209, 212-214, 219-224.

${ }^{29}$ Ślipko, Zarys etyki ogólnej..., 307-308.

${ }^{30}$ Merecki, Spór o prawo naturalne..., 48-52.

${ }^{31}$ Szostek, Prawo naturalne jako podstawa działania człowieka..., 42-43.
} 
tions are an expression of the Creator's will, who embedded certain purposes into human beings in the act of creation). ${ }^{32}$

However, the most common objection is the fallacy of biologism, the representatives of which treat human nature as morally binding. In the opinion of some contemporary philosophers and theologians, natural law does not consist in respecting the existing structures of nature, since it is flexible, subject to evolution and shaped by human beings. ${ }^{33}$ Consequently, any reference to the biological nature of the human being faces two significant obstacles. The first of them is an unauthorized transition from the fact ("is") to the norm ("should"). The latter occurs in natural biological tendencies to various, sometimes opposing aims, e.g. homo- or heterosexual activity. ${ }^{34}$

The above criticism resulted in the emergence of a new concept of natural law. As it has been mentioned earlier, it has its source in the thought of the philosophers representing the Enlightenment school of natural law, who equated this law with the natural reason orders. It can be claimed to have almost absolute autonomy, as it was detached from eternal law.

The new concept of natural law is also based on views expressed by some modern philosophers, originating mainly from the German-speaking areas. They include Immanuel Kant (autonomy of rational agents), Johann G. Fichte (self-manifestation of free "self"), Georg W.F. Hegel (the idea of progress in history), Friedrich Nietzsche ("will to power"), Karl Marx (concept of human needs), Jean P. Sartre (existentialism) and Martin Heidegger (Dasein providing sense). It was also largely influenced by Karl Rahner, who differentiated between the human being as an intelligible person and the human being as nature. In his opinion, a person can decide about himself or herself in freedom. However, nature is the condition of free actions of a person and self-development in the spirit of free choice. ${ }^{35}$

The above thoughts contributed to the emergence of the concept of a human being understood as freedom embedded in biological nature, which is resistant towards personal freedom and is governed by its own laws. However, he needs this nature to express freedom. In this situation, a human being is morally obliged to create a free self-project. Human nature was not given to man as a ready-made and closed reality, but rather as a subject to processes of individual and historical development. Therefore, historicity belongs to the essence of man and the world. Nevertheless, biological nature cannot be ignored, since it limits personal freedom to a certain extent. However, the personal entity is autonomous towards it, and called to create the truth about himself. Biological nature is a challenge for a human being, who should subordinate it to himself

\footnotetext{
${ }^{32}$ Merecki, Spór o prawo naturalne..., 21-36.

${ }^{33}$ Szostek, Natura, rozum, wolność..., 253.

${ }^{34}$ Merecki, Spór o prawo naturalne..., 28.

${ }^{35}$ Szostek, Natura, rozum, wolność..., 43-55, 99-101.
} 
and to the self-project he created. With this project, the sense will be given to life and to the world. It is not biological nature, but the creative self-portrait that has normative significance for the human being. It is all the more important since the act of human freedom expressed in the self-project is, out of its nature, the expression of God's will and, for this reason, it is absolutely morally binding. With realization of this self-project, which is understood as giving man an overall sense to himself, that development and self-fulfilment of the human being are possible. ${ }^{36}$

Moral normativity of natural inclinations in the traditional concept of natural law assumed a specific understanding of the ontic structure of the human being (biological nature), which was sometimes opposed to a person as a being transgressing it, being unrestricted with its laws and impulses. The person had an opportunity to rationally and freely determine the way in which to realize his nature. Moreover, he was morally obliged to this. Subordinating the personal to the natural could mean naturalization of the human person as a static being. Natural law would then become a set of orders grounded and derived from constant and unchangeable biological nature. However, such a vision raises doubts among supporters of the new concept. On one hand, it is difficult to show in the human being such unchangeable features due to his historical and cultural conditions. On the other, several elements can be indicated, without which it would be difficult to imagine human existence (e.g. the unity of soul and body, personality, interpersonal bond), but at the same time, it should be emphasized that those elements exist in variable realizations. Human variability can result in a change of behaviour and norms governing this behaviour. $^{37}$

It might seem that in the opinion of supporters of the new natural law concept, the idea of the precise differentiation of what is changeable and what is unchangeable in biological nature should be entirely abandoned, since variability belongs to the invariable human nature. What is invariable is the obvious fact that the human being is human. He not only has to discover the possibilities of his deeds and development on his own, but also to determine which of those possibilities are justified according to his self-project. In this situation, an individual judgement of conscience determines the norms of morality. Conscience becomes creative, since the human being decides on his own who he should and wants to be. ${ }^{38}$ In his cognitive conscience, it is more the objective aspect that is emphasized than the subjective one. It is here that the obligation of self-fulfilment is experienced. The self-project of the individual and his personal uniqueness are taken here into account. The adequacy of conscience

\footnotetext{
${ }^{36}$ Ibidem, 150-156, 256-257, 286.

${ }^{37}$ Merecki, Spór o prawo naturalne..., 37-46.

${ }^{38}$ Andrzej SZOSTEK, Wokót godności, prawdy i miłości, Lublin, Katolicki Uniwersytet Lubelski, 1998, 127-129, 281-282.
} 
judgements is measured according to their compliance with the authentic beliefs of the entity. ${ }^{39}$

Therefore, man differs from animals in that he is not entirely subject to the normalities of his biological nature. The task of a human being as a person is to give a personal sense to nature, following his individual understanding of himself. The human being and his self-understanding is therefore the norm of morality. However, self-understanding is based on the decision of the entity, which does not imply that the entity should understand himself in such a manner. Self-understanding is left entirely at the disposal of the human being who is its author. Although he has to take into account certain biological and social conditions, it is him who finally has to decide what he is going to recognize as the binding value. Those conditions are at most the source of inspiration for the individual. ${ }^{40}$ Love should be expressed as respect for human freedom, i.e. respect for how he understands and designs himself. ${ }^{41}$

Therefore, it can be claimed that in this concept we deal with absolutisation of human freedom. Freedom consists in the individual's determination of his self-understanding that is not determined by biological nature, as well as the principal direction of his development. This structure of freedom should be considered equal with natural law. For the human being, self-understanding, on the basis of which he formulates his free self-project, is morally binding. The evaluation of specific deeds is made in relation to the self-project of the entity. It is not the biological dimension of the human being that has moral significance, but his freedom. Although it is emphasized that carnality is important and necessary existential of human person, the human being can provide sense corresponding to his free self project. A human being exists in the body out of necessity, but his personal development is determined by the structure of free spirit. The body is not, therefore, treated as a factor significantly co-shaping the humanity of the human being, or a source of any absolute moral norms. ${ }^{42}$ Since freedom is superior to biological nature, a human being can independently decide about the relations in which he can enter with other people. Additionally, he can freely shape them. ${ }^{43}$

It should be noted that the human being is, above all, an autonomous entity, who has the possibility and task of self-determination. He relies on recognition of his own reason, through which he determines the sense that reality will have for him. Thus, he designs his life and deeds. In this situation, the biological nature of the human being is only a constituting co-principle, as the main principle is free reason. If a human being acts as a rational and free entity, he

\footnotetext{
${ }^{39}$ Merecki, Spór o prawo naturalne..., 97-104.

${ }^{40}$ Ibidem, 90-91, 95, 141, 159.

${ }^{41}$ Szostek, Natura, rozum, wolność..., 267-269.

${ }^{42}$ Ibidem, 291-293, 323-327.

${ }^{43}$ Bloom, Umyst zamknięty..., 133.
} 
preserves his dignity. Additionally, in the religious dimension, he fulfils God's will. $^{44}$

\section{Conclusions}

The analyses presented above had two principal aims. The first of them was to outline principal changes that the institution of marriage is currently undergoing. The second aim was to show problems related to the definition of natural law, which the supporters of traditional understanding of marriage as a union of a man and a woman refer to. The point of reference for this discussion is therefore the conviction about a certain relation between an understanding of marriage and the underlying concept of natural law.

On the basis of the discussion presented, the following conclusions can be reached. First of all, marriage is a natural form of social life, accomplishing specific purposes, not only with biological and psychological foundations, but also with social and relational aspects. Secondly, it provides a core for the family, by serving its procreation and upbringing function. Marriage also fulfils an important tasks in the development of human sexuality, which are important for the individuals and their relations (e.g. search for identity, attachment, mutual acceptance and surrender, experience of pleasure). Thirdly, on the one hand, a crisis of marriage is currently observed (e.g. low stability, divorces, concubinages), while on the other, we can see attempts to change its meaning and to redefine marriage by including (at least) same-sex relationships into it. Fourthly, followers of the traditional and the contemporary vision of marriage very often refer to natural law, searching in it for the reason to support their views, although they have different concepts concerning this law. Fifthly, a point of reference for representatives of the traditional vision is the concept of natural law which derives from the Aristotelian-Thomistic thought. Natural law is understood as the law of reason, which reads inclinations, motives for actions in the subjective spiritual-corporal structure (human nature). The subject of law is a rational being, who reads senses embedded in biological nature but does not create them arbitrarily. Nature is the measure of being and the way of participating in eternal law (God). God is the final reason explaining not only the contingency of the human being structure, but also the moral duty of nature. The human nature of moral features is the source of sense read by reason, which should take into account the normative meaning not only of spirituality, but also the corporality (sexuality) of the human being. Spirituality and corporality reveal the direction of development of a human being and require fulfilment by the gift of self, based on sexual differentiation,

\footnotetext{
${ }^{44}$ Merecki, Spór o prawo naturalne..., 83-88.
} 
which takes place within marriage. Sixthly, the common concept of natural law is based on distinguishing two dimensions in the human structure: personal freedom and flexible nature. Natural law is considered equivalent to arbitrary freedom of a human being. A free man creates, without nature determination, a self-project of his own life, which is of normative significance. Specific norms of morality are determined by creative conscience. The self-project is based on self-understanding of the human being, which is actually variable. Biological and social conditions are only a source of inspiration, since the human being finally determines its individual sense in the context of self-project. Corporality is, therefore, a certain existential element, which can be given a specific sense according to self-understanding and self-project of the individual. A human being is therefore an autonomous entity who, in his freedom, designs his reality with reason. He also designs his own life and interpersonal relationships he initiates, including marriage. Seventhly, it seems that the value of the traditional natural law, in which the entire nature of the human being is respected as a spiritual and corporal unity of being, requires greater recognition. Therefore, what is morally important is not only the spiritual dimension of the human being (reason), but also his material dimension (body). Human reason, reading the principles of natural law, should take into account to a fuller extent and cannot arbitrarily create a self-project for life. Therefore, human reason has dialogical function and autonomous subject has relational dimension. It is all the more important since self-understanding upon which it is based can be erroneous, for various reasons. It is the effect of reason, which does not often function in a proper way, and sometimes is even disturbed in its activity. Additionally, the lack of respect for the "language of corporality" can turn against the human being and his self-fulfilment. Eighthly, both concepts of natural law condition a specific understanding of marriage. In the first case, the spiritual and physical structure of the human being should be respected, the sense of which should be read and not arbitrarily given. Its sexual differentiation requires fulfilment with another person of the opposite sex, which takes place first of all in heterosexual marriage. In the second case, the human being as an individual does not have to take into account conditions resulting from the existing structures and can give them a sense according to his self-knowledge and project of his own life. This leads to conviction about the broader spectrum of possibilities of one's own development and other types of interpersonal relations, which are sometimes referred to as marriage. By the way, the question remains about the natural conditions of homosexuality and the possibility of sexually fulfilling people with this orientation. However, we will leave them unanswered, because it would require a deeper analysis, far beyond the issue we are interested in. Ninthly, a problem with defining marriage emerges. It seems that the existing definition of marriage should be preserved for the traditional heterosexual interpersonal community, assigning at the same time other terms for other types 
of interpersonal relations. It is particularly important in view of significant differences between those relations (e.g. procreation abilities), which should be reflected in terminology. With the aim to preserve precision of the terms used, the blurring of their meaning should not be attempted. Tenthly, an issue concerning legislative solutions concerning marriage and other types of relations still remains valid. In liberal-democratic states, where people of various world views and lifestyles live and work together, legal regulations should be created to establish proper frameworks for various interpersonal relations. However, we should not forget that the state has the right to support, even promote, certain types of interpersonal relations that are important from the perspective of the common good and future of the entire society. This includes marriage, which, apart from other important issues, ensures first of all the continued existence of the state community.

\section{Karol Jasiński* \\ Razumijevanje braka $i$ koncept prirodnog prava}

Sažetak

Autor članka postavio je dva glavna cilja. Prvi je cilj da se, na temelju naznačenih definicije braka, skiciraju temeljne promjene kojima je institucija braka trenutno podvrgnuta (kriza ciljeva, privatizacija, rastave, konkubinat, istospolni odnosi). Drugi cilj je prikaz problema vezanih uz priznavanje naravnoga prava, kojima se zagovara tradicionalno razumijevanje braka kao zajednice muškarca i žene. Polazi se od uvjerenja o stanovitom odnosu između razumijevanja braka i temeljnoga koncepta naravnoga prava. Prikazana su dva temeljna koncepta naravnoga prava: aristotelsko-tomistički i suvremeni, čije su posljedice navedene u zaključcima. Oba koncepta pretpostavljaju određeno razumijevanje ljudske naravi koja se u prvom slučaju tretira kao statična (duhovno-fizička struktura) i, u drugom slučaju, kao dinamična (inteligentna sloboda).

Ključne riječi: brak, ljudska narav, naravni zakon, savjest, sloboda.

\footnotetext{
* Izv. prof. dr. sc. Karol Jasiński, Varmijsko i mazurijsko sveučilišta u Olsztynu, Teološki fakultet; Hozjusza 15, 11-041 Olsztyn, Poljska; e-mail: karol.jasinski@uwm.edu.pl.
} 